\title{
PENGARUH KONFLIK PERAN TERHADAP TERJADINYA BURNOUT PADA MAHASISWA KOASS
}

\author{
Anggita Amelia Pangesti \\ Psikologi, Fakultas Ilmu Pendidikan, Universitas Negeri Jakarta \\ Rawamangun, Jakarta
}

Email: anggita_amelia@ymail.com

\begin{abstract}
The study was conducted 49 co-ass students who are doing clinical practice $(\mathrm{N}=49)$, investigate the effect of role conflict with the occurrence of burnout. Using a purposive technique sampling, these studies make use of two instruments as a measure of role conflict and burnout measurement tools that has been modified from the Maslach Burnout Inventory (MBI) with Likert models. The result is that there is significant influence between role conflict and the occurrence of burnout in co-ass students. The amount of influence (R Square) to the occurrence of role conflict and burnout is 0.389 (38.9\%) which means that the conflict affects the role of burnout by $38.9 \%$ and the remaining $61.1 \%$ influenced by other factors outside of role conflict. This indecated any significant positive effect of role conflict and the occurrence of burnout.
\end{abstract}

Keywords: co-ass, role conflict, burnout

\section{Pendahuluan}

Kesehatan merupakan aspek penting dalam kehidupan manusia. Sehat bukan berarti tidak adanya suatu penyakit tapi juga optimalnya kondisi fisik, mental, dan kesejahteraan sosial. Selama ini kalau berbicara tentang kesehatan hanya tertuju pada satu pokok pembicaraan yaitu penderita atau pasien saja, sedangkan petugas kesehatan seperti dokter, perawat, psikolog, pekerja sosial dan lain sebagainya yang bekerja bagi pasien atau klien sendiri pada umumnya jarang menjadi pokok pembicaraan. Padahal petugas kesehatan merupakan sumber daya manusia yang sangat penting dalam mengembangkan ilmu kesehatan dan juga sebagai pihak yang mendukung promosi di bidang kesehatan dalam bentuk penyuluhan mengenai bahaya-bahaya kesehatan dan usahausaha pencegahannya. Dokter sebagai salah satu petugas kesehatan merupakan profesi yang dianggap mempraktikkan ilmu kedokteran secara harfiah, dibandingkan dengan profesi-profesi perawatan kesehatan terkait (http://id.wikipedia.org/wiki/ Kedokteran).

Menurut Abrori (2007) dokter adalah tenaga kesehatan tempat kontak pertama pasien dengan tenaga kesehatan, untuk menyelesaikan semua masalah kesehatan yang dihadapi tanpa memandang jenis penyakit, organologi, golongan usia, dan jenis kelamin. Dokter sebagai elemen terpenting di Rumah Sakit diharapkan memberikan dedikasi yang tinggi terhadap pekerjaannya dalam hubungannya dengan pasien. Untuk memenuhi hal tersebut dokter melakukan tugasnya dengan memberikan pelayanan yang baik saat berhubungan dengan pasien. Hal ini sulit dilakukan karena kuantitas pasien yang dilayani tidak sebanding dengan jumlah dokter yang ada. Namun keadaan 
tersebut berbeda di setiap negara bahkan dalam satu negara (William, dalam Medical Ethics Manual, 2005).

China Daily melaporkan bahwa pada tahun 2010, terdapat 17.000 insiden kekerasan yang menimpa sekitar 70\% rumah sakit negara, termasuk pembunuhan. Pada akhir Maret, seorang dokter muda di Affiliated Hospital of Harbin Medical University di China timur laut, ditikam sampai mati oleh seorang pasien yang marah (http://luarnegeri.kompasiana.com/2012/04/30/menjadidokter-di-china-adalah-profesi-yang-berbahaya/). Secara umum situasi tersebut sepertinya lebih buruk. Banyak calon dokter yang merasa bahwa mereka tidak lagi dihormati sebagaimana mereka dulu dihormati. Oleh karena hal itu kompetensi harus dimiliki oleh seorang calon dokter yang nantinya akan melayani pasien atau klien, dimana relasi pasien dan dokter merupakan proses utama dari praktik kedokteran

(http://id.wikipedia.org/wiki/Kedokteran.

Calon dokter, dokter muda, atau koass adalah suatu jenjang pendidikan profesi yang dijalani oleh seorang lulusan sarjana kedokteran untuk dapat memperoleh gelar dokter umum dengan lama pendidikan koass adalah kurang lebih dua tahun. Selama kurun waktu tersebut, seorang koass harus melewati sebanyak 14 bagian stase kecil serta harus melewati 4 bagian stase besar (http://id.wikibooks.org/wiki/Catatan Dokter Mud a).

Secara umum seorang koass harus bersikap profesional kepada pasien serta tenaga medis lainnya selama menjalani praktik klinik. Disamping itu masih ada tugas lain dimana seorang koass mendapatkan tuntutan dalam menyelesaikan jenjang profesinya, yang harus mereka lakukan untuk syarat kelulusan, diantaranya membuat makalah tentang suatu kasus mulai dari definisi, patfis, prevensi yang nantinya akan dipresentasikan, mereka juga dituntut untuk belajar dan menyelesaikan tugas-tugas yang harus diselesaikan dalam waktu bersamaan. Sering kali tuntutan mereka saat berada di lingkungan rumah sakit menghambat kegiatan balajar mereka, sehingga sedikit waktu yang mereka miliki digunakan untuk beristirahat bukan digunakan untuk belajar.

Adanya tugas yang berbeda pada masingmasing peran kerja dan kewenangan yang berbeda, serta tuntutan yang berbeda pula dapat memunculkan konflik peran dalam diri koass dan memiliki konsekuensi atau dampak terhadap mahasiswa itu sendiri, rekan kerja, pasien, atau organisasi dalam hal ini rumah sakit tempat mereka bekerja. Menurut Baron \& Byrne (1997) peran adalah suatu set tingkah laku yang diharapkan untuk dilakukan oleh individu dalam menjalankan posisi tertentu dalam suatu kelompok dengan harapan dan tuntutan Harapan dan tuntutan ini menghasilkan batasan-batasan perilaku tertentu yang diharapkan untuk ditampilkan oleh individu tersebut.

Harapan dan tuntutan dari masyarakat terhadap peran yang dimiliki koass dapat menimbulkan ketegangan jika mereka tidak mampu menjalani masing-masing peran yang berbeda tersebut dengan baik. Dengan kata lain, jika seorang koass tidak mampu menjalani kedua peran tersebut dengan baik maka akan menimbulkan konflik peran dalam diri mereka, dalam hal ini seorang koas memiliki peran sebagai sebagai dokter dan sebagai mahasiswa magang (trainee). Meskipun kedua peran tersebut tidak sepenuhnya mengganggu, ketegangan yang melekat antara kedua peran tersebut pasti ada (Schaufeli, 2009). Misalnya, peran mereka sebagai mahasiswa mensyaratkan bahwa mereka harus belajar dari pekerjaan mereka, mengerjakan modul yang harus diselesaikan,dan deadline tugas. Disaat yang sama mereka diharapkan memberikan perawatan pasien yang efisien saat berperan sebagai dokter.

Dalam jurnal workaholism, burnout and wellbeing among junior doctors (Schaufeli. W, Bakker, et al, 2009) mengatakan bagaimanapun juga, ketika individu melakukan satu peran, maka individu tersebut tidak dapat melakukan peran lainnya dengan baik. Tuntutan yang mensyaratkan bahwa seorang koass belajar dari pekerjan dan pengharapan yang besar untuk memberikan perawatan pasien yang efisien membuat mereka menghabiskan jumlah waktu yang berlebihan dan energi di kedua peran, serta kemampuan tersebut dihabiskan dalam satu peran dengan mengorbankan peran lain, dan begitu pula sebaliknya, sehingga menyebabkan konflik intra-peran di tempat kerja. Selain itu terdapat juga tuntutan lain dimana seorang koass harus memproses sejumlah besar informasi dan membuat keputusan rumit (tuntutan mental), bekerja dalam lingkungan organisasi yang kompleks (tuntutan organisasi) dan harus berhadapan dengan pasien yang menderita dan keluarga mereka (tuntutan emosional).

Tuntutan kualitatif tersebut menghasilkan stres tambahan yang membuat seorang koass lebih sulit untuk melakukan dengan baik peran mereka sebagai dokter dan mahasiswa magang (trainee) sehingga memperparah konflik intra-peran. Stres tambahan ini membuat seseorang secara subjektif merasa ada "masalah" yang membebani drinya. Walaupun sebenarnya semua orang dapat mengalami stress, tetapi pembahasan mengenai stress lebih banyak dikaitkan dengan dunia kerja. Masalah yang membebani ini beresiko besar terhadap terjadinya kejenuhan yang sangat berhubungan dengan terjadinya burnout di dalam pekerjaan yang berhubungan langsung dengan manusia (human service work), karena profesi dokter merupakan salah satu bentuk pekerjaan yang 
berhubungan langsung dengan manusia dalam hal pelayanan jasa.

Burnout sebagai respon terhadap stres yang berlebihan atau akibat ketidakpuasan dalam pekerjaan, gejala tersebut merupakan salah satu bentuk coping yang dipilih individu untuk mengatasi stres dalam pekerjaan yang dihadapinya. Inividu menarik diri dari masyarakat, penarikan diri sendiri maksudnya adalah munculnya perilakuperilaku yang contohnya antara lain mudah tersinggung, menurunnya sikap positif terhadap masyarakat yang dihadapi, menyalahkan masyarakat, menghindar dari masyarakat yang seharusnya ditangani, berbuat sewenang-wenang, dan sebagainya. Gejala ini pada beberapa kasus muncul pada individu yang sebelumnya menunjukan dedikasi yang tinggi dalam pekerjaannya (Cherniss, 1980). Individu yang memasuki profesi pelayanan sosial "merasa terpanggil" sehingga idealisme mereka pun tinggi. Namun stress yang dialami secara kronis menyebabkan individu mengalami perubahan motivasi sehingga mereka mengalami burnout (Cherniss, 1980).

Tokoh lain, Freudenberger memandang burnout sebagai keadaan lelah atau frustasi yang disebabkan terhalangnya pencapaian harapan. Ia mengamati individu yang memulai berkarir memiliki idealisme. Ketika realitas yang ada tidak mendukung idealisme mereka maka individu tetap berupaya mencapai idealisme tersebut sampai akhirnya sumber diri mereka terkuras sehingga mengalami keadaan kelelahan atau frustrasi (Freudenberger \& Richelson, 1980).

Dari kedua pandangan tokoh mengenai definisi burnout dapat disimpulkan bahwa burnout merupakan suatu keadaan lelah atau frustasi yang disebabkan terhalangnya pencapaian harapan sehingga muncul perubahan sikap dan perilaku dalam bentuk menarik diri secara psikologis dari pekerjaannya, seperti menjaga jarak dengan klien maupun bersikap sinis terhadap mereka. Dari definisi mengenai burnout juga dapat diuraikan mengenai dimensi-dimensi burnout itu sendiri yaitu pertama Kelelahan Emosional (Emotional Exhaustion) yaitu kelelahan emosioal yang ditandai

\section{Metode Penelitian}

Subjek dalam penelitian ini adalah mahasiswa koass yang sedang melaksanakan praktik klinik di rumah sakit selama 6 bulan atau lebih. Subjek dalam penelitian ini adalah mahasiswa koass Rumah Sakit UKI. Jumlah kuesioner yang disebar sebanyak 60 buah, namun yang dapat dianalaisis sebanyak 49 buah. dengan terkurasnya sumber-sumber emosional, seperti perasaan lelah secara psikologis sehingga mereka merasa tidak mampu lagi untuk memberikan pelayanan dan sumber daya psikologis terhadap orang lain. Kedua, Depersonalisasi (Depersonalization) yaitu berkembangnya sikap negatif atau repon yang sinis dan pemberian jarak dengan penerima layanan dari suatu pelayanan atau pengasuhan yang diberikan seseorang. Terakhir, Penurunan hasrat pencapaian diri (Reduced of Personal Accomplisment) yaitu suatu evaluasi diri, dimana seseorang tidak lagi efektif dalam bekerja degan penerima layanan dan dalam pemenuhan tanggung jawab berkaitan dengan pelayanan yang diberikan, serta merupakan perkembangan sikap negatif yang berkaitan dengan tugas-tugasnya (Schaufeli \& Enzmann, 1998).

Burnout jelas merugikan karena akan mengurangi kemampuan dan efektifitas kerja para calon dokter. Burnout juga dapat berdampak buruk dimana dapat mempengaruhi pekerjaan dan pekerja itu sendiri, seperti keengganan untuk pergi kerja, adanya perasaan gagal, marah dan dendam, perasaan bersalah dan cenderung menyalahkan, kecil hati dan masa bodoh (ignoring), negativisme, mengisolasi dan menarik diri, merasa lelah dan letih yang berat setiap hari, kelelahan yang sangat setelah bekerja, kehilangan perasaan positif terhadap pasien, setelah masa kontak dengan pasien berakhir, menolak panggilan dari pasien, ketidakmampuan untuk berkonsentrasi atau mendengarkan apa yang dikatakan pasien, perasaan dilumpuhkan, sinis terhadap pasien, bersikap menyalahkan, serta kaku dalam berpikir serta bertahan untuk tidak berubah (Cherniss, 1980).

Berdasarkan fenomena serta teori yang telah dipaparkan, fenomena yang terjadi mengenai tututan tugas seorang koass seperti melayani pasien dengan professional, tuntutan dari pasien yang mengharuskan seorang calon dokter bekerja dengan cekatan, minimnya interaksi antara calon dokterpasien, hal ini disebabkan karena seorang calon dokter (koass) mengalami burnout akibat sumber daya yang terkuras habis juga situasi kerja yang menuntut secara emosi terus menerus, serta kuantitas pasien yang terlalu banyak.

Metode yang digunakan untuk mengumpulkan data dalam penelitian ini adalah kuesioner yang terdiri dari skala burnout (26 aitem) dan skala konflik peran (27 aitem). Untuk menganalisis kontribusi konflik peran terhadap terjadinya burnout pada subjek penelitian adalah dengan menggunakan analisis regresi sederhana. 


\section{Hasil dan Pembahasan}

Penelitian ini berusaha melihat kontribusi konflik peran terhadap terjadinya burnout pada mahasiswa koass. Pada awalnya dilakukan uji korelasi untuk melihat hubungan antara kedua variabel dengan menggunakan korelasi product moment diperoleh seperti pada Tabel 1 .

Tabel 1. Analisa Korelasi Product Moment

\begin{tabular}{|c|c|c|c|}
\hline \multirow[b]{3}{*}{ Pearson Correlation } & Correlations & \multirow[b]{2}{*}{$\begin{array}{c}\text { skor_BUR } \\
\text { NOUT }\end{array}$} & \multirow[b]{2}{*}{$\underset{\mathrm{CT}}{\operatorname{skor}}$} \\
\hline & & & \\
\hline & skor_BURNOUT & 1.000 & .624 \\
\hline \multirow{3}{*}{ Sig. (1-tailed) } & $\underset{\text { FLICT }}{\text { skor_ROLE_CON }}$ & .624 & 1.000 \\
\hline & skor_BURNOUT & . & .000 \\
\hline & $\begin{array}{c}\text { skor_ROLE_CON } \\
\text { FLICT }\end{array}$ & .000 & • \\
\hline \multirow[t]{2}{*}{$\mathrm{N}$} & skor_BURNOUT & 49 & 49 \\
\hline & $\underset{\text { FLICT }}{\text { skor_ROLE_CON }}$ & 49 & 49 \\
\hline
\end{tabular}

Hasil analisis tersebut menunjukkan adanya hubungan positif yang signifikan antara konflik peran dan burnout. Kesimpulan yang dapat diambil bahwa semakin tinggi konflik peran maka akan semakin tinggi terjadinya burnout pada mahasiswa koass dan semakin rendak konflik peran maka akan semakin rendah terjadinya burnout pada mahasiswa koass. Tuntutan-tuntutan kualitastif seperti adanya tuntutan secara mental, tuntutan dari organisasi, dan tuntutan secara emosional menghasilkan stress tambahan dimana seorang koass sulit untuk melakukan dengan baik peran-peran yang mereka miliki. Stress ini membuat seorang koass merasa memiliki beban yang berat yang akan beresiko terhadap terjadinya burnout (Cherniss, 1980).

Analisis regresi sederhana dilakukan untuk mengetahui kontribusi konflik peran terhadap terjadinya burnout dan diperoleh hasil seperti pada Tabel 2.

Hasil analisis diatas menunjukkan adanya kontribusi konflik peran yang signifikan terhadap terjadinya burnout, yaitu sebesar 38,9 \%. Konflik peran yang dialami akan menghambat produktivitas kerja dan kemangkiran kerja.

Tabel 2. Analisis Regresi Sederhana

\begin{tabular}{|c|c|c|c|c|}
\hline \multirow[b]{2}{*}{ Model } & \multicolumn{3}{|c|}{ Model Summary } & \multirow[b]{2}{*}{$\begin{array}{c}\text { Std. Error of the } \\
\text { Estimate }\end{array}$} \\
\hline & $\mathrm{R}$ & R Square & $\begin{array}{l}\text { Adjusted R } \\
\text { Square }\end{array}$ & \\
\hline 1 & $.624^{\mathrm{a}}$ & .389 & .376 & 7.215 \\
\hline
\end{tabular}

Konflik antar peran sebagai dokter dan mahasiswa magang pada seorang koass cenderung mengarah pada terjadinya burnout dimana terdapat ketidakseimbangan antara tuntutan dalam pekerjaan dan keamanan individu untuk mengatasi masalah. Tekanan sering kali terjadi pada individu saat lebih banyak waktu yang dihabiskan pada satu peran saja, sedangkan peran lainnya yang juga memiliki tuntutan terabaikan (Schaufeli, W, Bakker, 2009).

Berdasarkan hasil penelitian yang telah dilakukan, faktor yang mempengaruhi burnout bukan hanya konflik peran saja. Hal ini dibuktikan dengan nilai koefisien determinasi sebesar 0.389 berarti konflik peran mempengaruhi terjadinya burnout mahasiswa koass sebesar 38,9\% dan sisanya $61,1 \%$ dipengahi oleh faktor-faktor lain antara lain lingkungan kerja yang bersumber dari beban kerja, ambiguitas peran, dukungan sosial, dan gaya kepemimpinan, dan faktor individual seperti introvert dan locus of control eksternal, dan hal-hal lain yang tidak diteliti pada penelitian ini.

Hasil penelitian ini juga mengindikasikan bahwa ketidakmampuan mahasiswa koass menjalankan dua peran sekaligus yaitu dokter dan mahasiswa magang dan bagaimana mereka menjalin hubungan dengan orang lain yang berada 
di lingkungan kerjanya maka hal tersebut dapat memberikan pengaruh positif pada terjadinya burnout. Artinya bahwa mahasiswa koass yang

\section{Kesimpulan dan Saran}

Hasil uji korelasional menunjukkan adanya hubungan positif yang signifikan antara konflik peran dan terjadinya burnout. Hal ini berarti semakin tinggi konflik peran yang dialami subjek maka akan semakin tinggi terjadinya burnout, demikian juga sebaliknya, semakin rendah konflikperan yang dialami subjek maka akan semakin rendah terjadinya burnout.

Hasil uji regresi sederhana menunjukkan adanya kontribusi konflik peran secara signifikan terhadap terjadinya burnout pada subjek, dengan besar kontribusi 38,9\%. Hal ini berarti 38,9\% terjadinya burnout pada subjek dipengaruhi oleh konflik peran yang dialami subjek, sedangkan $61,1 \%$ dipengaruhi oleh faktor-faktor lainnya.

Bagi peneliti selanjutnya disarankan untuk meneliti faktor-faktor yang dapat meneyebabkan burnout. Selain harus diperhatikan dalam perencanaan penelitian seperti penambahan jumlah responden agar hasil penelitian lebih representatif untuk populasi. Lebih lanjut, pertimbangan mengenai karakteristik responden, pengkonstrukan instrument atau alat ukur yang lebih mapu mewakili konsep variabel penelitian, serta penggunaan metode pengumpuan data yang lebih menunjang, juga termasuk beberapa hal yang perlu mendapat perhatian lebih lanjut untuk pelaksanaan penelitian-penelitian selanjutnya.

\section{Daftar Pustaka}

Abrori, C. 2007. Perbedaan antara dokter dan dokter keluarga. Jakarta: Perhimpunan Dokter Keluarga Indonesia.

Anastasi, A. \& Urbina, S. 2007. Tes Psikologi. Jakarta: PT. Indeks

Armeini R, A. 2010. Analisis Data Penelitian Kuantitatif Dengan SPSS. Psikologi UNJ: Tidak diterbitkan.

Azwar, S. 2009. Metode Penelitian (Cetakan Kesembilan). Yogyakarta: Pustaka Pelajar.

Baron, R.A \& Byrne,D. 1997. Social Psychology $\left(8^{\text {th }}\right.$ ed). USA: Allyn and Bacon mengalami konflik peran berpengaruh terhadap terjadinya burnout.

Caputo,J.S. 1991. Stress and Burnout In Library Service. Canada: Oryx Press

Cherniss, Cary . 1980. Staff burnout. Job Stress in the human service. Beverly Hills Sage Publications.

Cox, T., Kuk, G., \& Leiter, M.P.1993.Burnout, Health, Work Stress, And Organizational Healthiness. Dalam W.B. Schaufeli, C. Maslach, \& T. Marek (Eds.), Professional Burnout: Recent Departement in Theory And Research (pp.58-66). Washington DC: Taylr \& Francis.

Coyney,J.C., \& Lazarus,R.S. 1980. Cognitive Style, stress, perception, and coping. Dalam I.L. Kutash \& L.B. Schlesinger (Eds), Handbook of stress and anxiety:Contempory knowledge, Theory, and treatment. San Francisco: Jossey-Bass.

Febriana, Anna. 2002. Burnout pada Perempuan yang Bekerja Sebagai Caregiver (Skripsi). Fakultas Psikologi Universitas Indonesia.

Freudenberger, H.J. 1989. Burnout: past, present, and future concerns. Dalam D.T Wessels, Jr., A.H. Kutscher, I.B. Seeland, F. E. Selder, D.J. Cherico, \& E.J. Clark (eds.), Professional burnout In Medicine and The Helping Professions (pp.1-10). New York:The Haworth Press.

Freudenberger, H.J.,\& Richelson,G. 1980. Burnout: The High Cost of Success and How to Cope with It. London: Arrow Book.

Freudenberger, Herbert J.1974. Staff burnout. Journal of Social Issues. 30, 150-1665.

Holroyd, K.A., \& Lazarus, R.S. 1982. Stress, Coping, and Somatic Adaption. Dalam L. Goldberg, \& S. Breznitz (Eds.). Handbook of Stress: Thereotical And Clinical Aspects. New York: The Free Press.

http://id.wikibooks.org/wiki/Catatan Dokter Mu $\underline{\text { da }}$

http://id.wikipedia.org/wiki/ Kedokteran 
http://luar-

negeri.kompasiana.com/2012/04/30/menjadidokter-di-china-adalah-profesi-yangberbahaya/ posting 30 April 201209.43

http://siapjadidokter.wordpress.com/kehidupanmahasiswa-vs-koass/mahasiswa-vs-koas/kata-dokter-yang-udah-praktek/

http://staff.blog.ui.ac.id/nani.cahyani/files/2009/1 2/buku-pedoman-praktik-klinik-

http://www.dikti.go.id/Archive2007/kepmendikna s no $045 \mathrm{u} 2002$.

Kerlinger, Fred N. 1995. Asas-asas Penelitian Behavioral (Edisi Ketiga). Yogyakarta: Gajah Mada University Press.

Konsil Kedokteran Indonesia, 2006. Standar Kompetensi Dokter, Edisi Pertama.

Linzey, G., \& Aronson, E. 1968. The hand book of social psychology, $2^{\text {nd }}$ ed. Massachussetts: Addison-Wesley Publishing Company.

Maslach, C. 1993. Burnout: A Multidiensi Perspective. Dalam W.B. Schaufeli, C. Maslach,\& T. Marek (Eds), Profession Burnout: Recent development in theory and research (pp.19-32). Washington DC: Taylor \& Francis.

Maslach,C. 1982. Burnout: The Cost of Caring. New Jersey: Prentice-Hall, Inc.Ferber, B.A. 1991. Crisis in Education: Stress and Burnout In America Teacher. San Fransisco: JosseyBass Publisher.

Mereike, Flaviani. 2005. Peranan Gaya Kepemimpinan Atasan Terhadap Burnout Pada Perawat Rumah Sakit (Skripsi) Fakultas Psikologi Universitas Indonesia.

Murtiasari, Eka. 2006. Anteseden dan Konsekuensi Burnout Pada Auditor: Pengembangan Terhadap Role Stres Model (Tesis). Program Magister Science Akutansi Universitas Diponegoro.

Myers,D. 1988. Social Psychology. Singapore:McGraw - Hill, Inc.
Prameswary, Dyah. 2007. Gambaran Burnout pada Caregiver Keluarga Pasien Stroke (Skripsi) Fakultas Psikologi Universitas Indonesia.

Robbin, Stephen P. 2003. Organizational Behavior. New Jersey: Prentice Hall.

Schaufeli, W, Bakker, et al. Workaholism, burnout and well-being among junior doctors:The mediating role of role conflict. Routledge.

Sedarmaryanti. 2007. Manajemen Sumber Daya Manusia. Bandung: Refika Aditama.

Singer, J.E, \& Davidson, L.M. 1986. Specificity and stress Research. Dalam M.H. Appley \& R.Trumbull (Eds), Dynamics of Stress: Physiological, Psycholgical, and social perspectives (pp.47-59). New York: Plenum Press.

Sugiono, DR. 2009. Metode Penelitian Kuantitatif, Kualitatif dan R\&D. Bandung: CV. Alfabeta.

Sullivan, I.G.1989. Burnout: A Study of A Psychiatric Center. Wessels,Jr., A.H. Kutcher,I.B.Seeland, F.E.Selder, D.J.Cherico,\&E.J.Clark(eds.), Professional Burnout in Medicine and The Helping Professions (pp.83-90). New York: The Haworth Press.

Usman, Husaini. 1995. Pengantar Statistika. Yogyakarta: Bumi Aksara.

Wexley, Yuki. 2001. Perilaku Organisasi dan Psikologi Personalia, Jakarta : Rineke Cipta.

Williams, John R, Medical Ethics Manual. 2005. Pusat Studi Kedokteran Islam Fakultas Kedokteran: Universitas Muhammadiyah Yogyakarta via website http://www.wma.net/en/30publications/30eth icsmanual/pdf/ethics manual indonesian.pdf diunduh pada tanggal 1 Maret 2012 13:18. 